\title{
PHYTOCHEMICAL SCREENING OF ETHANOLIC EXTRACT: a Preliminary Test on Five Medicinal Plants on Bangkalan
}

\author{
Laila Khamsatul Muharrami ${ }^{1}$, Fatimatul Munawaroh ${ }^{2}$, Taslim Ersam ${ }^{3}$, Mardi Santoso ${ }^{4}$ \\ ${ }^{1,2}$ Natural Science Education, Education Faculty University of Trunojoyo Madura, Bangkalan, Indonesia \\ ${ }^{1}$ laila@ trunojoyo.ac.id, ${ }^{2}$ fatim@trunojoyo.ac.id \\ ${ }^{3,4}$ Chemistry Department, Faculty of Natural Science, ITS, Surabaya, Indonesia \\ paktichem@gmail.com, ${ }^{4}$ tsv09@chem.its.ac.id
}

Accepted: October 1, 2020

Published: October 31, 2020

DOI: https://doi.org/1921107/jps.v7i2.8722

\begin{abstract}
This study is preliminary research of secondary metabolite potential from medicinal Herb Madura. This study aims to know the medicinal plants used in the medicinal herb Madura and the phytochemical content contained in these medicinal plants. The method used in this study is a survey to know the kinds of medicinal plants used in Madura Herb. Then a phytochemical screening test for the medicinal plant was performed. The phytochemical screening test used are alkaloids, steroids, saponins, and flavonoids. Based on the research, it is found that 66 medicinal plants are widely used for "Ramuan Madura" in Bangkalan. Of the 66 plants selected, Madura five medicinal plants widely used by the Madurense; Parameria laevigata, Kaempferia galanga L., Curcuma domestica, Curcuma xanthorrhiza, dan Punica granatum. Then the preliminary phytochemical test to determine the secondary metabolite compounds. Secondary metabolite content obtained include alkaloids, saponins, steroids, and flavonoids.
\end{abstract}

Keywords: Medicinal plants, Preliminary phytochemical screening, Secondary Metabolite

${ }^{1}$ Corresponding Author 


\section{Introduction}

Madura is one of the islands known as Herbal Potions. Madura herb is a cultural ancestor that must be maintained and preserved (Handayani, 2003). The Madura potion made by the community consists of two types, (i) the Madurense herb made by the herbal medicine seller (Jamu Gendong) or from the industry and (ii) made by the herbalist (Li, Cai, Liu, Sun, \& Luo, 2019). Madura herbs use raw materials derived from herbal plants. In addition to herbal medicine's raw material, medicinal plants are also sources of information about secondary metabolite content, which can further be developed as a drug with an appropriate selectivity test. The most important bioactive compounds are tannins, alkaloids, phenolic compounds, and flavonoids. Correlation lies in between the bioactivity of plants and the Phytoconstituents, which are known to synthesize compounds to specific activities to treat various healths. Therefore, a preliminary test of phytochemical screening is needed to find and develop alternative materials to improve herbs' efficacy. Several studies have also been conducted.

Based on observation and field surveys in the Bangkalan area, 66 herbs are often used in Madura herbs. Herbal medicine is used in raw materials for making Madurense herbs in treating various diseases such as Galian rapet, selokarang, Galian patmosari, empot-empot, and Rumput fatimah. Among the 66 herbal plants, the most widely used herbs are "rapet" wood, turmeric, kencur, temulawak, and pomegranate. The five herbal plants are then tested by using the preliminary phytochemical test. It aims to determine the content of secondary metabolite compounds contained in the herbs. So, found whether there is a correlation between the properties of herbal plants and their chemical content.

\section{Research Methods \\ Plant Materials}

Stem of Parameria laevigata, rhizomes of Kaempferia galanga L., rhizomes of Curcuma domestica, rhizomes of Curcuma xanthorrhiza, and Punica granatum and also ethanol.

\section{Preparation of Extracts}

The herbs that have been dried and then mashed to become powder. Furthermore, about $300 \mathrm{~g}$ of the powder is dissolved into a $900 \mathrm{~mL}$ solvent at room temperature and then filtered.
Extracts obtained were filtered, concentrated, and allowed to dry till constant weight was obtained.

\section{Phytochemical Screening}

All the extracts plants $(0.05 \mathrm{~g} / \mathrm{ml})$ were prepared for preliminary phytochemical screening based on standard methods for detecting the following components.

\section{Flavonoid Test}

Alkaline reagent test

Approximately $3 \mathrm{~mL}$ of plant extract was treated with $1 \mathrm{~mL}$ of $10 \% \mathrm{NaOH}$ solution. The formation of the intense yellow color showed an indication of the presence of flavonoids.

\section{Saponins Test}

Approximately $3 \mathrm{ml}$ of plant extracts were added to $3 \mathrm{ml}$ of distilled water and shaken vigorously. The formation of a stable, persistent froth was taken as a positive test for saponins.

\section{Steroids Test}

Approximately $2 \mathrm{~mL}$ of chloroform and concentrated $\mathrm{H}_{2} \mathrm{SO}_{4}$ were added to $5 \mathrm{~mL}$ of the prepared plant extracts. A layer of red color indicated the presence of steroids in the lower chloroform.

\section{Alkaloids Test}

Approximately $500 \mathrm{mg}$ of Simplicia powder was stirred with a few of $2 \mathrm{~N} \mathrm{HCl}$ and $9 \mathrm{~mL}$ of aquadest, then heat on the water for 2 minutes. The mixtures were then cooled and filtered. The filtrate was used to perform a test with various reagents (Table 1).

Table 1. Test with various alkaloid reagent

\begin{tabular}{lll}
\hline No & Alkaloids Reagents & Observation \\
\hline 1 & Dragendoff's test & $\begin{array}{l}\text { The formation of a reddish- } \\
\text { brown precipitate }\end{array}$ \\
\hline 2 & Mayer's test & $\begin{array}{l}\text { The formation of a greenish } \\
\text { colored or cream precipitate }\end{array}$ \\
\hline
\end{tabular}

\section{Result and Discussion}

The samples used in this study are Parameria laevigata, Kaempferia galanga L., Curcuma domestica, Curcuma xanthorrhiza, and Punica granatum. The five medicinal plants were dried in a place that is not exposed to direct light to aim that the secondary metabolite content in the sample is not damaged. The dried sample was then crushed. The refinement process seeks to increase the sample's surface area so that the contact between the sample and the solvent is extensive so 
that the extract in the sample dissolves quickly in the solvent.

From the five medicinal plants, the preliminary phytochemical tests of Medicinal plant extracts of different parts of five medicinal plants Parameria laevigata, Kaempferia galanga L., Curcuma domestica, Curcuma xanthorrhiza, and Punica granatum. The phytochemical test shows secondary metabolite compounds that can provide efficacy in the herbs (Table 2).

\section{Parameria laevigata}

Parameria laevigata is usually used to treat ulceration, wounds, dysentery, and uterine pain after parturition. The organic extract is traditionally obtained from the stem of Pameria laevigata. Based on the study results, it was found that Pameria laevigata contained flavonoids, saponins, and steroids (Table 2). This is reinforced by previous research that Pameria laevigata contains flavonoids (Sundari D et al., 2005; Almira U, 2015), saponins, steroids (Barus, S.H. et al., 2019).

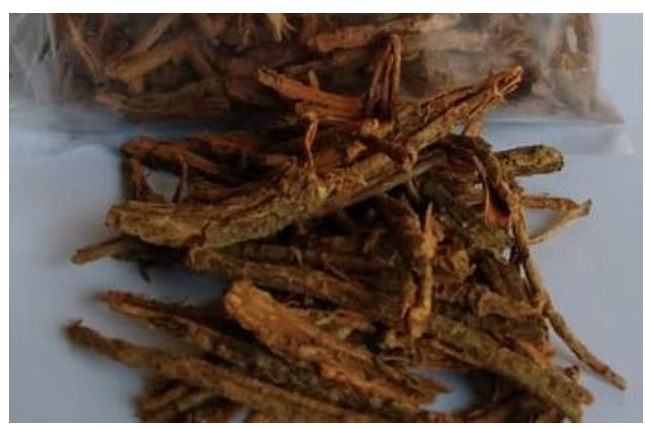

Figure 1

Parameria laevigata

\section{Kaempferia galanga $L$}

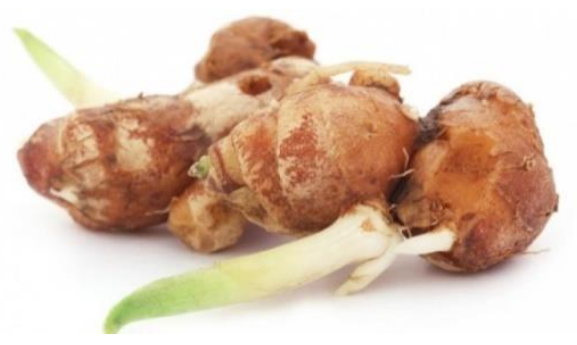

Figure 2

Kaempferia galanga $L$

Kaempferia galanga $L$. belonging to the Zingiberaceae family is an important medicinal plant with potent restorative activities. Drug utilization is related to its secondary metabolites. Plants produce secondary metabolites as an adaptation or for defense in an unfavorable environment. Kaempferia galanga $\mathrm{L}$ has been widely known in the community as a food spice and for medicinal purposes, including coughing, nausea, ulceration, and anti-toxins. The components contained include saponins, flavonoids, polyphenols, and essential oils (Gholib $\mathrm{D}, 2009$ ).

\section{Curcuma domestica}

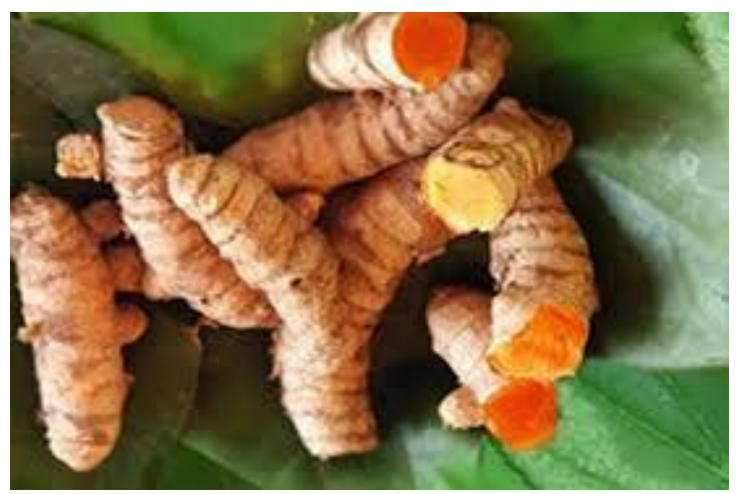

Figure 3

Curcuma domestica

Curcuma domestica has many benefits and uses, namely medicinal medicine, to increase endurance, prevention, treatment, and treatment of various diseases. Curcuma domestica, the main biologically active component of Curcuma domestica, is curcumin. The research has shown that curcumin has potent antioxidants, wound healing, and anti-inflammatory properties, proving to be therapeutic against acne. Curcuma domestica is considered safe in the amounts found in food and when taken orally or topically in medicinal doses. It can cause atopic dermatitis in some people. However, pregnant women are not recommended because it can stimulate the uterus.

\section{Curcuma xanthorrhiza}

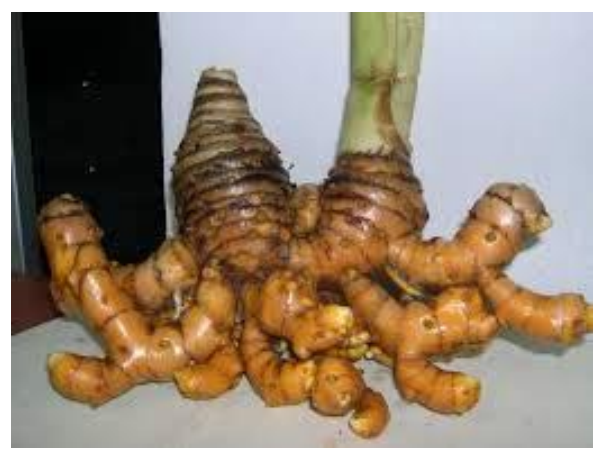

Figure 4

Curcuma xanthorrhiza

Temulawak (Curcuma xanthorhiza) is a family medicinal plant. Zingiberaceae is widely grown and used as raw material for traditional 
medicines in Indonesia. Temulawak is known to have many benefits, one of which is potential as antioxidants. Active components that are responsible for antioxidants in the rhizome Curcuma are curcumin. Temulawak rhizome contains various chemical ingredients such as curcumin, 48-54\% starch, and 3-12\% essential oil.

Essential oil is a liquid that is yellow or orange-yellow, has a strong odor. The composition of essential oils depends on the age of the rhizome, isolation technique, place of growth, analysis technique, variety, etc. (Dalimartha 2000). The essential oil from ginger rhizome contains compounds of telandren, camphor, borneol, cineal, xanthorrhizol, isofuranogermacren, tricycline, alloaromadendren, and germakren. These compounds and curcumin's content causes Curcuma to be efficacious for treatment (Taryono et al. 1987; Kurnia 2006 in Oktaviana 2010 and Khaerana et al. 2008).

\section{Punica granatum}

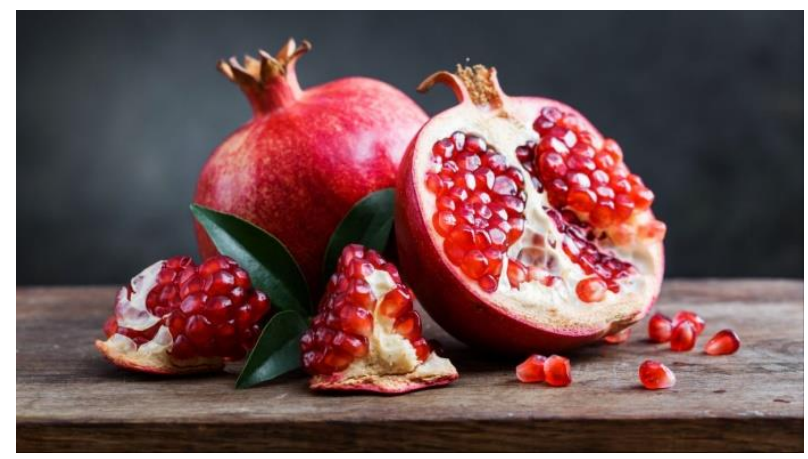

Figure 5

Punica granatum

Punica granatum L has medicinal properties such as anti-inflammatory (Hernawati, 2015), therapy for hypertension (Syafrilia, 2018), and antibacterial activities (Prestiandari, Hernawati, \& Dewi, 2018). The seed oil of Punica granatum phytoestrogen compounds in phenolic compounds with intense antioxidant activity (Syafrilia, 2018). Based on the research has shown that curcumin has possessed flavonoids, saponins, and steroids. Curcuma domestica supports it as safe in the amounts found in food and when taken orally or topically in medicinal doses. It can cause atopic dermatitis in some people. However, pregnant women are not recommended because it can stimulate the uterus.

\section{Flavonoids}

Flavonoid is compounding polyphenols which consisting of C6-C3-C6 rings (rings $\mathrm{A}$ and $\mathrm{B}$ ) linked by ring $\mathrm{C}$ (Fig.1) (Wang, Li, \& Bi, 2018). Flavonoids are present in all green plants to be found on each plant extract (Arifin \& Ibrahim, 2018). Based on the phytochemical tests indicate the presence of flavonoids in all five medical plants screened. It is evident by observing the yellow color in all the extracts. Flavonoids have bioactive agents against inflammatory diseases(García-Lafuente \& Guillamón, 2012), cancer, neurological (Shehzad et al., 2016), and antioxidants (Arifin \& Ibrahim, 2018).<smiles>O=c1cc(-c2ccccc2)oc2ccccc12</smiles>

Figure 6. Basic Structure of Flavonoids (Wang et al., 2018)

\section{Saponins}

Saponins have relatively high molecular weight. Saponin tests were carried out on the plant materials using a qualitative procedure with foam test and color test. The occurrence of saponins can be characterized by a relatively stable form of foam (Ashour, El Aziz, \& Gomha Melad, 2019). Based on the result, found that four samples contain saponins (wood "rapet," kencur, temulawak, and pomegranate). The saponins structure is non-polar, which causes saponins like soap or detergent (Fahrunnida \& Pratiwi, 2015). Some saponins are known to be capable of deactivating viruses (Francis, Kerem, Makkar, \& Becker, 2002), antimicrobial(Soetan, Oyekunle, Aiyelaagbe, \& Fafunso, 2006), and antiinflammatory effects (Audina \& Khaerati, 2018).

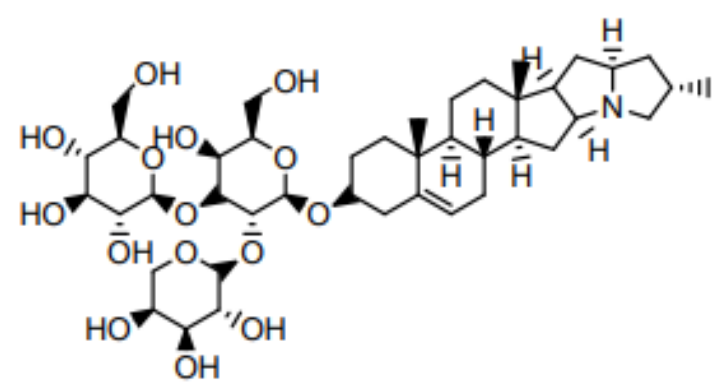

Figure 7. Basic Structure of Saponins (Noer, Pratiwi, \& Gresinta, 2018) 


\section{Steroids}

In the Steroid test, Liebermann-Burchard reagents to test for the presence of steroid compounds. The formation of orange shows positive steroids. The five selected medicinal plants are found positive for steroids. Plant steroids have many properties, including antibacterial activity (Hidayah, Kusrini, \& Fachriyah, 2016), anti-inflammatory agents (Patel Assistant Professor, Savjani Assistant Professor, Patel, \& Savjani, 2015), and anticancer (Ilyas, Novianty, \& Irmayanti, 2015).

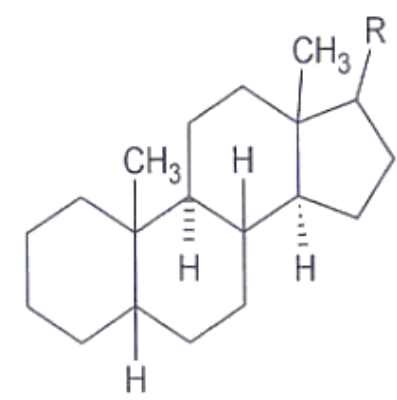

Figure 8. The basic structure of Steroids (Salempa \& Muharram, 2015)

\section{Alkaloids}

In the alkaloid test, only temulawak contains positive alkaloids. It is characterized by its formation on the Wagner reagent test to form brown colored precipitates, and in the Degandroff reagent test, orange-colored deposits are formed. Alkaloids that have been reported to exert antispasmodic, antibacterial activities and analgesics. Alkaloids also have cytotoxic activity.

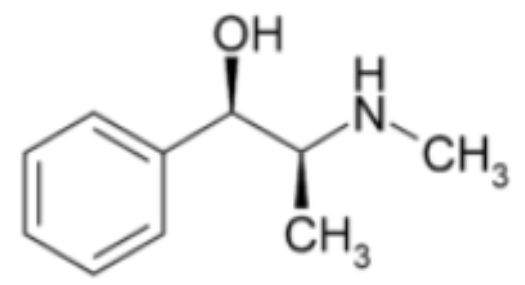

Figure 9. The basic structure of Alkaloids

Table 2. Phytochemical Screening from Medicinal Plants

\begin{tabular}{|c|c|c|c|c|c|}
\hline No & Medicinal Plants & Saponins & Steroids & Alkaloids & Flavonoids \\
\hline 1 & $\begin{array}{l}\text { Stem of Parameria laevigata } \\
\text { (kayu rapet) }\end{array}$ & + & + & - & + \\
\hline 2 & $\begin{array}{l}\text { Rhizomes of Curcuma } \\
\text { domestica (kunyit) }\end{array}$ & - & + & - & + \\
\hline 3 & $\begin{array}{l}\text { Rhizomes of Kaempferia } \\
\text { galanga L.(kencur) }\end{array}$ & + & + & - & + \\
\hline 4 & $\begin{array}{l}\text { Rhizomes of Curcuma } \\
\text { xanthorrhiza (temulawak) }\end{array}$ & + & + & + & + \\
\hline 5 & Punica granatum (delima) & + & + & - & + \\
\hline
\end{tabular}

\section{Conclusion}

The ethanol extract of Parameria leavigata has revealed the presence of saponins, steroids, and flavonoids. Curcuma domestica has revealed the presence of steroids and flavonoids. Kaempferia galanga L. has revealed the presence of saponins, steroids, alkaloids, and flavonoids. Curcuma xanthorrhiza has revealed saponins, steroids, alkaloids, and flavonoids. Punica granatum has revealed the presence of saponins, steroids, and flavonoids. The preliminary screening tests may help detect bioactive principles and develop drug/medicine based herb. Alkaloids have been well investigated for many pharmacological properties, including antioxidants, antiinflammatory,

\section{Acknowledgment}

This paper is part of the research results funded by DRPM, the Director-General of Research Strengthening and Development of the Ministry of Research, Technology, and Higher Education. For this, the authors express many thanks for the support of these funds. We also 
thank the LPPM, University of Trunojoyo Madura, Science Education students, and those who supported this research's smoothness and success.

\section{References}

Arifin, B., \& Ibrahim, S. (2018). Struktur, Bioaktivitas Dan Antioksidan Flavonoid. Jurnal Zarah, 6(1), 21-29. https://doi.org/10.31629/zarah.v6i1.313

Ashour, A. S., El Aziz, M. M. A., \& Gomha Melad, A. S. (2019). A review on saponins from medicinal plants: chemistry, isolation, and determination. Journal of Nanomedicine Research, 7(4), 282-288. https://doi.org/10.15406/jnmr.2019.07.00199

Audina, M., \& Khaerati, K. (2018). Efektivitas AntiinflamasiI Ekstrak Etanol Daun Sumambu ( Hyptis capitata Jacq .) Pada Tikus Jantan ( Rattus norvegicus L .). Bocelebes, 12(2), 17-23.

Fahrunnida, \& Pratiwi, R. (2015). Kandungan saponin buah, daun dan tangkai daun belimbing wuluh (Averrhoa bilimbi L .). Seminar Nasional Konservasi Dan Pemanfaatan Sumber Daya Alam, 1(1), 220 224.

Francis, G., Kerem, Z., Makkar, H. P. S., \& Becker, K. (2002). The biological action of saponins in animal systems: a review. British Journal of Nutrition, 88(6), 587-605. https://doi.org/10.1079/bjn2002725

García-Lafuente, A., \& Guillamón, E. (2012). Anti-inflammatory properties of dietary flavonoids. Handbook on Flavonoids: Dietary Sources, Properties and Health Benefits, 22(3), 409-425.

Handayani, L. (2003). Membedah rahsia ramuan Madura. Retrieved from https://agromedia.net/katalog/membedahrahasia-ramuan-madura/

Hernawati, S. (2015). Ekstrak Buah Delima sebagai Alternatif Terapi Recurrent Apthous Stomatitis (RAS). Jurnal Kedokteran Gigi, 12(1), 20-25. Retrieved from https://jurnal.unej.ac.id/index.php/STOMA/ar ticle/view/2745/2216

Hidayah, W. W., Kusrini, D., \& Fachriyah, E. (2016). Isolasi, Identifikasi Senyawa Steroid dari Daun Getih-Getihan (Rivina humilis L.) dan Uji Aktivitas sebagai Antibakteri. Jurnal
Kimia Sains Dan Aplikasi, 19(1), 32. https://doi.org/10.14710/jksa.19.1.32-37

Ilyas, A., Novianty, I., \& Irmayanti, I. (2015). Senyawa Golongan Steroid dari Ekstrak Steroid dari Ekstrak n-Heksana Kulit Batang Kayu Bitti (Vitex cofassus) Dan Uji Toksisitas Terhadap Artemia salina Leach. Chimica et Natura Acta, 3(3), 120-124. https://doi.org/10.24198/cna.v3.n3.9220

Li, Z. H., Cai, M., Liu, Y. S., Sun, P. L., \& Luo, S. L. (2019). Antibacterial Activity and Mechanisms of Essential Oil from Citrus medica L. var. Sarcodactylis. Molecules, 110.

https://doi.org/10.3390/molecules24081577

Noer, S., Pratiwi, R. D., \& Gresinta, E. (2018). Penetapan Kadar Senyawa Fitokimia (Tanin, Saponin dan Flavonoid) sebagai Kuersetin Pada Ekstrak Daun Inggu (Ruta angustifolia L.). Jurnal Eksakta, 18(1), 19-29. https://doi.org/10.20885/eksakta.vol18.iss1.ar t3

Patel Assistant Professor, S. S., Savjani Assistant Professor, J. K., Patel, S. S., \& Savjani, J. K. (2015). A systematic review of plant steroids as potential anti-inflammatory agents: Current status and future perspectives. The Journal of Phytopharmacology JPHYTO, 4(42), 121-125. Retrieved from www.phytopharmajournal.com

Prestiandari, E., Hernawati, S., \& Dewi, L. R. (2018). Daya Hambat Ekstrak Buah Delima Merah (Punica granatum Linn) terhadap Pertumbuhan Staphylococcus aureus (The Inhibition of Red Pomegranate Fruit Extract (Punica granatum Linn) on The Growth of Staphylococcus aureus). Pustaka Kesehatan, 6(1), 192. https://doi.org/10.19184/pk.v6i1.7157

Salempa, P., \& Muharram. (2015). Senyawa Steroid Dalam Tumbuhan Bayur.

Shehzad, A., Anwar, M. N., Zahid, H., Ravinayagam, V., Al-Rumaih, H. S., AlKhulaifi, F., ... Al-Suhaimi, E. A. (2016). Multifactorial role of flavonoids in prevention and treatment of various cancers Title in Spanish: Papel multifactorial de los flavonoides en la prevención y tratamiento de algunos cánceres. An Real Acad Farm No, 82(3), 297-302.

Soetan, K. O., Oyekunle, M. a, Aiyelaagbe, O. O., 
\& Fafunso, M. a. (2006). Evaluation of the antimicrobial activity of saponins extracts of Sorghum Bicolor L. Moench. African Journal of BiotechnologyJournal of Biotechnology, 5(23), 2405-2407.

Syafrilia, T. D. W. N. W. R. M. (2018). Anti Hipertensi Minuman Serbuk Instan Campuran Ekstrak Buah Delima Merah (Piper crocatum) pada Tikus Hipertensi. Food Science and Technology Journal, 1(2), 11-25.

Wang, T. Yang, Li, Q., \& Bi, K. shun. (2018). Bioactive flavonoids in medicinal plants: Structure, activity, and biological fate. Asian Journal of Pharmaceutical Sciences, 13(1), 12-23.

https://doi.org/10.1016/j.ajps.2017.08.004 